\title{
Study of Business English Translation Based on the Three Rules of Skopos Theory
}

\author{
Zhang Lili ${ }^{1}$ \\ ${ }^{1}$ Beijing Wuzi University, Beijing, China \\ mywritingclass@163.com
}

Keywords: Skopos Theory; Three Rules; Business English Translation, Application.

\begin{abstract}
The Skopos theory for a long time remains as the nuclear of Function School of translation. It focuses on translation as an activity with an aim or purpose, and on the intended addressee or audience of the translation. The major three rules of Skopos theory serve as the orientation and direction for the business English translation. Based on the analysis of these rules of Skopos theory and special characters of business English language, this paper focuses on the application cases of business English translation guided by the Skopos theory and suggests its great significance in practice . It aims to shed some light on the translation theory and practice in business English field and contribute to the further research and study in business English translation.
\end{abstract}

\section{Introduction}

The Skopos theory is an approach to translation which was put forward by Hans J Vemeer and developed in Germany in the late 1970s. Skopos theory is the core of German Functional School. It oriented a more functionally and socioculturally concept of translation, whereby translation is considered not as a process of translation, but as a specific form of human action. The word "Skopos" was from Greek, meaning purpose or aim. It's used as the technical term for the purpose of the translation. The main idea of Skopos theory is that translators should hold the thought from the perspective of the target readers during the process of translation. Therefore, translators should keep in mind what the function of translation text is, what the target readers' demand is and even what communicative situation is (Vermeer, 1996). Consequently, the choice of translation strategies is decided by the purpose of the translation text, in order to achieve a better function text. In the frame work of this theory, one of the most important factors determining the purpose of a translation is the address, who is the intended receiver or audience of the target text with their world language. Every translation is directed at an intended audience. The theory focuses above all on the purpose of the translation, which determines the translation methods and strategies that are to be employed in order to produce a functionally adequate result. Vermeer regards it as an "offer of information" that is partly or wholly turned into an "offer of information" for the target audience. From this view, the status of the source is clearly much lower in Skopos theory than the equivalence theory (Vermeer, 2000).

\section{Three Main Rules of the Skopos Theory.}

According to Hans J Vermeer and following translation theory experts, there are three main rules of the Skopos theory: skopos rule, coherence rule and fidelity rule. 
Skopos Rule. Skopos is a Greek word for "aim" or "purpose". "The top-ranking rule for any translation is thus the 'skopos rule', which means that a translation action is determined by its skopos; that is, 'the end justifies the means"' by Reiss and Vermeer. Vermeer also stresses on many occasions that the skopos rule is a general rule, and translation strategies and methods are determined by the purpose and the intended function of the target text.

Coherence Rule. The coherence rule states that the target text "must be interpretable as coherent with the target text receiver's situation" (Vermeer, 1984). In other words, the target text must be translated in such a way that it is coherent for the target text receivers, given their circumstances and knowledge. In terms of coherence rule, the source text is no longer of most authority but only part of the translation beliefs. It is only an offer of information for the translator, who in turn picks out what he considers to be meaningful in the receiver's situation.

Fidelity Rule. Translation is a preceding offer of information. It is expected to bear some relationship with the corresponding source text. Vermeer calls this relationship "intertextual coherence" or "fidelity". This is postulated as a further principle, referred to as the "fidelity rule" by Reiss and Vermeer in 1984.The fidelity rule merely states that there must be coherence between the translated version and the source text. In the relationship among the rules, fidelity rule is considered subordinate to coherence rule, and both are subordinate to the skopos rule. If the skopos requires a change of function, the criterion will no longer be fidelity to the source text but adequacy or appropriateness with regard to the skopos. And if the skopos demands intra-textual incoherence, the standard of coherence rule is no longer vivid (Nord, 2001).

\section{Distinctive Features of Business English Language}

Business English is an important branch of ESP (English for Special Purposes), which is composed of all English language texts applied in business fields. It basicly presents informative texts and communicative texts. In essence, business English translation is supposed to transfer business texts from the original language to the target language, and it is a process of cross-cultural business communication. Due to the specific characteristics of business activities, business English translation has special features of its own.

Terminology. A large number of special terms are used in business English. FOB, CIF, force majeure, insurance policy, balance sheet and securities are some examples. The appropriate usage of the terminology plays an important role in business English communication, therefore, the correct translation of them becomes essential. This poses a challenge to business English translator who is required to get some basic gist of business expertise knowledge and practice skills.

Accuracy and Formality. Formality and preciseness is a very distinctive feature of business English linguistic style. In some special business occasions, the language is used in extreme accuracy and rigorousness. Some non-finite verbs and passive voice are frequently applied to this effect. For example, "We are delighted to receive your letter of March 20 asking whether we can supply you with Article No.12." and "The liabilities include sums or damages as may have been awarded by the arbitration board". This therefore requires translators pay much attention to this special language features.

Acronyms and Derivatives. Since the development of globalization and special characters of business field, various new acronyms and derivatives are wildly used in business English language. For example, COD (cash on delivery), B/L (bill of lading), A/C (account), ENCL (enclosed), IRO (in respect of), and free loan, short sales, etc. On the one hand, the use of these acronyms and derivatives facilitates all kinds of business communication and greatly improves its efficiency; on the other hand, it aggregates the difficulties of the business English translation. 


\section{Application of the Three Rules of Skopos Theory in Business English Translation}

The skopos theory focuses on translation as an activity with an aim or purpose, and on the intended addressee or audience of the translation. The skopos theory provides the direction and guidance for the business English translation. Business English is a kind of application language in business area, and business English translation requires of strong orientation to recipients or target users. Its functional purposes suggest business texts should be translated to satisfy its practical functions. The major three rules orientates the application of this theory in translation practice. The prospective function or skopos of the target text is determined by the initiator's, i.e. client's, needs. Consequently, the skopos is largely constrained by the target business text user (reader/listener) and his/her situation and cultural background. The coherence rule stipulates that the target business text must be sufficiently coherent to allow the intended business partners to comprehend it. The fidelity rule concerns intertextual coherence between target business text and source business text to facilitate business communication eventually. Therefore, an perfect integrating point can be struck between the skopos theory and business English translation: "reader-centered" or "target-culture-oriented". The skopos theory is served as both a macro orientation and micro strategies for business English translation.

Application Case of "Skopos Rule". According to the "skopos rule", the satisfaction of targeted business text recipient is the key factor of business English translation. In business English translation, the targeted "skopos" are to translator, to target text, to business strategy. Taking advertising text translation as an example, translator is required to satisfy the designated purpose of effective communication between the advertisement and its text recipients. The targeted audience are supposed to be attracted, informed, touched and convinced by the advertising text even under the different cultural backgrounds. To this end, the transaltion must be guided by the "skopos rule", and some translating techniques like adding, deleting, adaptation and rewriting must be applied to satisfy the expected purposes. Some classic and beautiful translations of advertising slogans are: "Where there is a way, there is a Toyota." "Delighting you always." "To the last drop."

Application Case of "Coherence Rule". The "coherence rule" states that the target business text must be translated in such a way that it is coherent for the target business receivers, given their situational contexts and knowledge. In this kind of business English translation, the smooth and effective communication should be highlighted. Taking the translation of business contracts as an example, translators should pay much attention to the formality and appropriateness of the legal language in business occasions, and find the right way to make the target text coherent and accurate for the readers. Otherwise, not only the language problem but the business failure may be resulted in this respect. The following is a typical case of good translation: "It is strictly understood that the seller shall not be held responsible for non-delivery or delayed delivery of the goods ordered if the situation is caused by force majeure, war, rebellion, fire, strike, new levies imposed by government, inability of, or refusal by the manufacturers to fulfill the contract or any other causes beyond the seller's control.”

Application Case of "Fidelity Rule”. "The fidelity rule” emphasizes there must be coherence between the target text and the source text. The fidelity of business English translation refers to a logical, precise, and cross-culturalequivalent shift from source language to translated text. The degree of fidelity, to a great extent, can be showcased by the accurate translation of business terms and special business expressions. Any distortion or ambiguity in business English translation is a serious violation of this rule. Here is an example of quality business English translation by this rule: "The quote price of foreign currency is based on the prevailing official exchange rate in China between the said foreign currency to Renminbi. Any devaluation of the foreign currency to 
Renminbi at the time of negotiating the draft shall be for the buyer's risk and account.”

\section{Conclusion}

Skopos theory is a great breakthrough in the development of translation theories. In skopos theory, the status of the source text is lower than it is in equivalence-based theories of translation. Paul Kussmaul writes about this theory: "the functional approach has a great affinity with Skopos theory. The function of a translation is dependent on the knowledge, expectations, values and norms of the target readers, who are again influenced by the situation they are in and by the culture. These factors determine whether the function of the source text or passages in the source text can be preserved or have to be modified or even changed...” (Paul, 1989). With the deepening of globalization, business English is more and more widely used in the cross-cultural and business-like communications. The application of the skopos theory in the business English translation breaks many barriers of mal-communication in business and solve many language problems in the way of trans-national business activities. The three major rules of Skopos theory, i.e. skopos rule, coherence rule and fidelity rule, proves to be good guidance for business English translation, and will play a more important role in this field.

\section{Acknowledgements}

Fund Project: This paper is phasic research outcome of the 2016 BWU Youth Fund Project "Research and Practice of Business English Translation Based on Skopos Theory" .

\section{References}

[1] Nord, Christiane. (2001). Translating as a Purposeful Activity: Functionalist Approaches Explained [M]. Shanghai: Shanghai Foreign Language Education Press.

[2] Vermeer, Hans J.(1989). Skopos and Commission in Translational Action [M]. Helsinki: Oy Finn Lectura Ab.

[3] Vermeer, Hans J. (2001). A Framework for a General Theory of Translation [M]. Shanghai: Shanghai Foreign Language Education Press.

[4] Liu, X. F. (2013). The application of skopostheorie in business English translation [J]. Journal of Tangshan College.

[5] Wang, X. M. (2013). Study of translation errors in scientific paper C/E translation based on skopostheorie [J]. Northwest Medical Education.

[6] Sun, X., \& Nie, Z. (2013). Study on business English translation based on functional translation theory. Journal of Beijing University of Aeronautics \& Astronautics. 